\title{
Lymphocyte Antigen 6K
}

National Cancer Institute

\section{Source}

National Cancer Institute. Lymphocyte Antigen 6K. NCI Thesaurus. Code C126134.

Lymphocyte antigen $6 \mathrm{~K}$ (165 aa, $19 \mathrm{kDa}$ ) is encoded by the human LY6K gene. This

protein may be involved in cell growth. 